\title{
Addressing Career Services' \\ Internationalisation Challenges Through \\ Transnational Consortia
}

\author{
Jérôme Rickmann, Adriana Perez-Encinas, and Nadia Fernandez-de-Pinedo
}

\section{Introduction}

Providing optimal support on employability for students and graduates has become an integral part of the role of HEIs. In the US, international students tend to seek job opportunities, which is probably why universities such as the University of Southern California and New York University 'provide resources and professional development workshops on job search processes and strategies' (Nara et al. 2019) as a way to improve demand and supply. In the case of Europe, the Bologna Process led to an increase in the implementation of career services at European HEIs to strengthen the employability of their institutions' graduates (cf. eg. Sultana 2017).

In fact, in the 2014-2016 period, internships abroad have shown an upward trend (European Commission 2018a). Universities have developed strategies to internationalise their structures and to favour international mobility. In particular, the number of students involved in international internships grew by $14 \%$, from 73,338 students (and recent graduates) in the first year of the Erasmus + programme implementation to 84,190 students in 2016 (European Commission 2015; European Commission 2018a).

The provision of student services has become a key topic among academics and various stakeholders due to the growing numbers of mobile students (Perez-Encinas 2017). The high quality provision of support services can attract and retain interna-

J. Rickmann

Centre for Higher Education Internationalisation, Università Cattolica del Sacro Cuore,

Milan, Italy

e-mail: jerome.rickmann@unicatt.it

A. Perez-Encinas $(\varangle) \cdot$ N. Fernandez-de-Pinedo

Universidad Autónoma de Madrid, Madrid, Spain

e-mail: adriana.perez.encinas@uam.es

N. Fernandez-de-Pinedo

e-mail: nadia.pinedo@uam.es

(C) The Author(s) 2020

A. Curaj et al. (eds.), European Higher Education Area: Challenges for a New Decade, https://doi.org/10.1007/978-3-030-56316-5_4 
tional students and satisfy their expectations. Moreover, providing them with superior structures and opportunities locally and internationally can enhance their general experience (ACE 2016). In this respect, this paper explores how work and internship mobility, as well as career services, operate at an international and national level. Two central questions are answered by means of an exploratory method. Firstly, are European career services equipped to adapt to the increasingly international dimension of their work, such as integrating international students into the labour market or helping them to find internships abroad? Secondly, how could international career service consortia support HEIs' global ambitions?

\section{International Internships and the Benefits of Studying Abroad}

The increasing number of internationally mobile students reflects the expansion of tertiary education systems worldwide (OECD 2013). Consequently, it is claimed that a more comprehensive approach to the internationalisation of higher education (Hudzik 2014) will increase the awareness that HEIs have to become more inclusive and less elitist by not focusing predominantly on physical mobility but more on the curriculum and learning outcomes (European Parliament 2015). In 2014, the ERASMUS + programme was launched as the successor to the ERASMUS programme, into which mobility schemes were integrated that were previously separate, thus promoting the mobility of an increased number of students under more typologies than was previously possible. The EU's programme, with a budget of $€ 14.7$ billion, provides opportunities for more than 4 million Europeans to study, train, gain experience and volunteer abroad. In particular, its aim is to tackle high levels of (youth) unemployment and reduce poverty by promoting education system modernisation. It also encourages the cooperation and partnership of higher education providers, aside from serving as a vehicle for social inclusion, intercultural comprehension and networking (European Commission 2018a). In addition to this strategy, the European Commission has launched a new virtual mobility action called the Erasmus +Virtual Exchange, taking advantage of today 's digital learning tools to complement the physical mobility programme in Europe. Social skills and a sense of initiative could be two learning outcomes, among others, that virtual mobility could enhance (Vinagre 2016).

Students who participate in international mobility face new challenges and unfamiliar situations that might enable them to develop autonomy and self-confidence. According to the Erasmus Impact Study (2014), students participating in internships abroad were able to interact and work with people from other backgrounds and cultures. Moreover, they adapted to new situations and, at the end of their internships, they were more interculturally competent. They had also gained foreign languages skills and a broader knowledge of the host country's culture, society and economy. 
Erasmus+ promotes the acquisition of knowledge and competences that might not be taught at home but are demanded by employers to satisfy today's business needs (European Commission 2015; European Commission 2018b). In this sense, working abroad is a valuable opportunity for students to improve their CVs (European Commission 2014), for instance by stressing newly developed skills, such as mastering a foreign language, or acquiring new understandings and developing personal attributes (Yorke 2006, p. 8). In fact, Van Mol (2017) found that international education was particularly valued when employers needed graduates with good foreign language and decision-making skills.

In the European context, the international dimension of higher education started to be managed less by incidental and individual initiatives than in the past. It began to be increasingly structured into organised activities, projects and programmes based on political rationale. It also became increasingly driven by national governments rather than by HEIs (De Wit and Merkx 2012). The internationalisation of higher education also influenced the organisation of support services. Erasmus' support for traineeship has gradually grown in importance since Erasmus+ was launched. In the three years since implementation, about 235,000 students have gone abroad on traineeships, with 20,500 of them being recent graduates (European Commission 2018b).

In particular, career services play an important role in supporting students in their school-to-work transition and in the acquisition or improvement of crucial skills and competences to gain initial employment (e.g. problem- solving skills, multi-cultural environments, networking and socialising, initiative and entrepreneurship), according to Altmann and Ebersberger(2012). The traditional way of providing career services is changing in response to current trends and new pressures. Do Céu and De Nazaré (2014) argue that career services could provide students with seminars, workshops, career counselling and information to support the school-to-work transition. Moreover, career services can also assist students by making them aware of the existence of mobility study programmes or internships abroad that could enable them to enhance their employability in the global context. Knight and Yorke (2003) suggested that employability might be improved through work experience, entrepreneurship modules, a portfolio of achievements and (good quality) career advisers. However, the delivery of support services varies significantly across European HEIs, with students getting information and support from a variety of sources instead of a central and unified structure. For instance, international students might have to ask for information, advice or support from offices which were originally created to support only exchange students or mobile student enrolment (Kelo and Rogers 2010). Additionally, especially in European institutions, there seems to be a lack of research literature around the internationalisation of career services that is not written from an Anglo-American perspective and which provides in-depth knowledge about heterogenic developments (cf. for American universities, e.g., Kenyon and Rowar-Kenyon 2014). The importance of a broader view was highlighted a decade ago by Kelo and Roger s (2010) following an innovative study conducted in six European countries (Denmark, France, Germany, Italy, Poland, and UK). In line with this study, Mikulás and Jitka (2019) explored acculturation experiences by analysing a 
database containing the questionnaire responses of international students studying abroad (France, Germany, Italy, Spain and Portugal). One of the findings was that the cultural impact of mobility was positive and most favourable in Germany.

However, many European HEIs still find it difficult to satisfy international students' needs, because in many cases support services differentiate between domestic and international students, and the domestic services are not in all cases adapted to tackle the needs of international students or those willing to go abroad. Taveira (2017) argued, for example, that career services have to adopt a more holistic approach and introduce psychological and guidance services for students.

\section{Method}

This paper is exploratory in nature; the aim is thus not to generalise or to evaluate with statistical certainty. As a first step, we conducted desk research and combined and interpreted known statistics and surveys about career services, mainly in Europe, under a new research interest. Based on the presentation of the current state of career services, a case study approach was adopted with a view to exploring the benefits of a career service consortium model. We conducted an exploratory holistic single case analysis (cf. Yin 2018; see also Ridder 2016). Since the 1980s, case studies have been a popular research method in a wide range of disciplines, from the social sciences to health, with a variety of perspectives and approaches being utilised to understand complex realities. In education, the pioneers were Stake (1995), Merriam (1998) and Simons (2009). According to Stake (1995, p. xi) 'a case study is expected to catch the complexity of a single case'. Consequently, even a single explanatory case study would be sufficient to extrapolate results (Yin 2009). The particular case was chosen because the authors were involved with career consortium implementation, which afforded us in-depth insights into the unit of analysis. While the authors' close involvement in the study might have resulted in bias, this was limited since the purpose of the study was to develop propositions for further research and not to judge or assess the overall impact or quality of the work conducted. The data was gathered mainly during evaluation sessions, in which the project participants discussed the progress made during the project, and through evaluation surveys to assess the various activities of the consortium. Additionally, we had access to funding proposals, internal documentation and project outputs. We worked through the material 'from the ground up' (Yin 2018, p. 169-170) and analysed it using a hermeneutical approach similar to Yin's logic models (cf. Yin 2018).

\section{How Prepared Are Career Services to Facilitate Global Student Work Mobility in Europe?}

As indicated previously, there are still many grey areas when assessing and comparing the role of career services internationally, especially when it comes to something as specific as their internationalisation. The structural situation of career services 
in Germany and their internationalisation efforts are, however, relatively well documented. In the following section, we will, therefore, examine the case of Germany in detail and contextualise it with findings from other countries (Netherlands, Sweden, Canada, Romania, Spain, Italy, France, the UK and the USA). Whilst this procedure does not offer sufficient knowledge to provide a quantitative global answer to the above question, it helps to outline where further research is needed and what the focus should be. Moreover, it supports the initial argument that more intra- and inter-institutional cooperation is needed.

In 2014, the German Rector's Conference (HRK) conducted a survey amongst German career services and international offices, asking about their internationalisation efforts (Böhm and Brandl 204). In 2015, the same stakeholders, that is, the German Rectors' Conference and the Career Service Network Deutschland e. V., published a general report on the structural situation of career services in Germany (CSND 2015). Additional data to compare the German case with the international scenario was derived from the Expert Council of German Foundations on Integration and Migration's (ECGFIM) study 'Train and Retain. Career Support for International Students in Canada, Germany, the Netherlands and Sweden' (2015). Data published by the Qareer-project (2017), which conducted a cross-national study with a special focus on Italy, Romania, Spain and Poland, was also sourced. The main findings provide a good indication of the current state of affairs and highlight the urgent need for more reliable academic research.

The HRK survey (Böhm and Brandl 204) results show that German HEIs have started to internationalise their career services. More than $78 \%$ of the answering institutions stated that they provided activities to internationalise their services (e.g. trainings, projects, specific classes), which shows that these institutions recognise to a certain extent that facilitating support for the international dimension of careers is one of their responsibilities.

When asked about their main target group, about $61 \%$ of the institutions identified international students trying to integrate into the German labour market, whilst $39 \%$ stated that the focus of their internationalisation activities was on local graduates.

The responsibility for the integration of international students into the German labour market is largely assigned to career services (57\%), which in Germany are usually central departments at higher education institutions $(78.9 \%)$. This is also reflected in the career services' budgets, in which activities aimed at international students receive the largest budget share (compared to activities specifically for men, women, doctoral students, disabled students and dropouts) (CSND 2015).

The main challenges are that the foreign student body might not be accustomed to the specifics of the German labour market. These students might also experience workplace discrimination and be hampered by language barriers. Consequently, most career services aim to minimise the effects of these 'disadvantages', typically via workshops on the job application process, individual coaching for international students, and language and intercultural training (Böhm and Brandl 204). This is true for most countries, according to the 'Train and retain' report (ECGFIM 2015). German HEIs, similarly to Swedish universities, focus their services mainly on students who are about to graduate, whilst Canadian and Dutch HEIs tend to start early after enrol- 
ment and offer support throughout the study cycle (ECGFIM 2015). Even though German institutions score highly compared to Canada, Sweden and the Netherlands in terms of targeting their services at international graduates, it is only in the Netherlands that the strategic integration of international alumni in the job market is a popular activity of career service work (ECGFIM 2015).

Unfortunately, there is insufficient data to directly assess the extent of these measures and their impact, which is a recognised issue, when assessing the impact of career service work (Eimer 2014). While it is assumed that career services provide a useful service, the extent to which students benefit from them is unclear.

From an organisational perspective, communication restrictions are an issue when trying to reach students. However, even more severe is the resource question, which makes a continuous need-focused, ready-on-demand service delivery rather unlikely. Thanks to the 'Train to retain' report (ECGFIM 2015) and the HRK survey (CSND 2015), one has a rough idea of the student-to-staff ratios in career services (Canada: 2,922:1; Germany: 7,283:1; The Netherlands 8,765:1; Sweden: 4,999:1). Though these numbers differ quite a bit from institution to institution, it is fair to say that it is close to impossible to imagine that all students could benefit from individual attention and counselling. Considering that the student-to-staff ratios at international offices (Canada: 2,770:1; Germany: 2,082:1; The Netherlands 2,445:1; Sweden: 1,941:1) are rather low, it seems that organisational priorities (expressed in funding and resource allocation) do not favour career departments. The answers to the survey questions about the sustainability of internationalised services clearly indicate a lack of resources (Böhm and Brandl 204).

As the authors of the 'Train to retain' study write: 'Despite international students' need for more systematic and coordinated job entry support at the local level, most of them encounter a poorly coordinated patchwork of occasional career fairs, job application training and chance acquaintances with service staff or company representatives who may or may not be able to help them' (ECGFIM 2015, p. 4).

The countries in the abovementioned study are among the rather well-off countries. Moreover, while in Germany, for example, most career services were established only 10 years ago, countries such as Romania started even later with the establishment of university career services on a larger scale (Cojocariu and Puiu 2014). The uneven development of career services in Europe is also one of the reasons for which there are no commonly shared international standards of career service work (Qareer 2017), which further begs the question of how career services professionals are trained. Whilst the UK is leading in offering qualifications related to career guidance as fully recognised study programs on a university level in the European context, such a high degree of professionalisation is the exception rather than the rule in Europe (cf. Qareer 2017).

After having looked at the inbound perspective related to the integration of international students, let us have a look at the outbound perspective. How are career services helping their students to find work abroad?

There is a lot of financial support in the EU for students to support mobility. Students can apply for ERASMUS+ internship funds and/or government funding (e.g. BAFöG) for some financial help when they go abroad (in 2013/2014 the 
National Agency that manages ERASMUS funds in Germany alone allocated about $€ 10,000,000$ for 6,500 students to do internships abroad and additional funding schemes are available).

According to the HRK's survey (Böhm and Brandl 204), about $39 \%$ of career services identified home students as the main target of their internationalisation activities. Organising workshops that aim to enable students to find work abroad and/or intercultural training aiming to prepare graduates for a global work environment are the most popular services offered. Survey responses suggest, however, that institutions quite often do not possess the necessary knowledge internally and have to rely on external coaches to conduct workshops, which means they might be not able to satisfy information needs when in actual demand but only at specific times. About $29 \%$ provide job boards, on which international job advertisements are also published. It is unclear how many students are able to benefit from the workshops or how well-connected career services are internationally. European universities rarely provide structured schemes to place students with companies abroad, in contrast to many North-American universities (cf. Kenyon and Rowan-Kenyon 2014).

To sum up, if all the aspects outlined above are considered, a patchwork impression prevails. Though one finds admirable efforts at institutions and there has never been a time when more has been done to support international work mobility, there still is a great deal of work to be done to improve services to support global work mobility. Hudzik's (2014) call for comprehensive internationalisation also needs to be answered in career service work. Currently, we find a multitude of activities which are somewhat related to in- or outbound mobility and labour market integration, but only limited discussion about what internationalisation should mean in the context of career service work and how institutions can address the problem of a lack of resources, networks and knowledge to adapt to the demand of preparing a truly global workforce.

\subsection{Case Study: Benefitting From Inner- and Intra-institutional Cooperation}

As indicated above, two of the main challenges for career centres in HEIs in terms of their endeavour to support their students are scarce resources and a lack of prioritisation. It is a costly endeavour to build knowledge of foreign labour markets, to produce target group-specific activities and resources for international students to integrate into the local economy and to build worldwide company collaborations. The necessary institutional resources are seldom in place to implement a systematic strategy and aligned effective operations.

One possible solution could be participation in career service consortia. Considering the amount of HEIs worldwide, there is enormous potential to connect and collaborate in order to improve students' career mobility, that is, student migration flows, with the aim of working (internship or entry- level) abroad. Rooted in the con- 
text provided so far, we present in this part the lessons learnt from an ERASMUS+ strategic partnership project that aimed to address many of the challenges outlined above and to improve the service offer in the institutions involved in a transnational career service consortium operating under the name 'European Centre for Career Development and Entrepreneurship' (ECCE).

The ECCE consortium was established between Universidad Autónoma de Madrid, Università Cattolica del Sacro Cuore, Regent's University London, the Paris School of Business and EBC Hochschule. The preparation phase started in 2014, and in 2015, the initiative received funding through the ERASMUS+ Key Action 2-strategic partnerships.

The project partners aimed to create a small consortium that should, at its core, work like a second- level support system for career officers and support those officers directly on an operational level, meaning helping them to advise and place their students abroad. This involved colleagues from different countries collectively developing and sharing materials, training each other on labour market standards in their respective countries, regularly liaising with each other and responding to specific questions from their student-facing colleagues. The aim of this approach was to (a) improve the availability of international know-how at all times and not only when external coaches were present; (b) extend the institutional reach (that is, sharing company networks rather than trying to develop your own); and (c) push inner- and intra-institutional cooperation through the involvement of a diverse set of stakeholders. Besides the traditional career service responsibilities, the partners decided to add entrepreneurship education to their consortium portfolio in order to enhance cooperation within their own institutions and between institutions. The latter decision enabled project-based summer schools on Entrepreneurship in Europe to train students. The basic assumption was that the core of entrepreneurship education was to foster problem-solving skills and initiative because both traits are beneficial for students aiming for a corporate career; hence, there was a clear link to career service work (ECCE 2015).

The summer school curriculum was developed by involving academics and project managers from all institutions, and the summer school delivery also involved all institutions. Doing so allowed the career service officers to expand their workshop offers, reach out and collaborate with colleagues from international offices. Most importantly, it also involved academics and entrepreneurs, which again brought their entrepreneurship knowledge and networks to the table. It furthermore enabled them to gain international teaching experience and provided them with the opportunity to cooperate with like-minded academics from the partner institutions (ECCE 2017a).

The heart of this network is a platform on which the partners share resources, such as job-boards and application guides, and offer the possibility to match academics, students and other stakeholders who have an interest in entrepreneurship in terms of research or actual start-up cooperation. This has been accompanied by staff training weeks for career service members and summer schools to foster entrepreneurial skills amongst students in order to develop internationally-aware staff and students. The aim remains to keep the network small and foster deep relations between the career officers involved so that they truly benefit from their enlarged network in their day- 
to-day operations. At the same time, ECCE promotes the model and its experiences since it wants other institutions to copy the model.

\subsection{The ECCE Model}

Two central questions were addressed, namely: are European career services equipped to adapt to the increasing international dimension of their work (e.g. integrating international students in local labour markets or supporting their students to find work abroad) and how could international career service consortia support HEIs' global ambitions? Figure 1 answers these questions by proposing the ECCE model built by the authors, in which four main elements should be taken into account: a joint platform and guides, joint training, joint networks and joint entrepreneurship summer schools. In this model, it is important to involve and connect with stakeholders in each country: students, administration (e.g. career services, IOs), academics, companies and other organisations.

The long-term impact of the initiative remains to be seen, but preliminary feedback indicates that pursuing such a model (as represented in Table 1) could be worthwhile in relation to career services, summer schools and collaborations between institutions. As noted by Larrance (2002, p. 9), 'the commitment to the long term must be present in order to succeed, and success in leveraging resources will follow if these areas are recognised and thoroughly explored'.

In the abovementioned concept paper, the ECCE team stresses the following as critical for those considering implementing a similar structure:

'The main challenge for a consortium is not so much the creation of technical resources and tools to share, but to foster a team spirit across universities and coun-

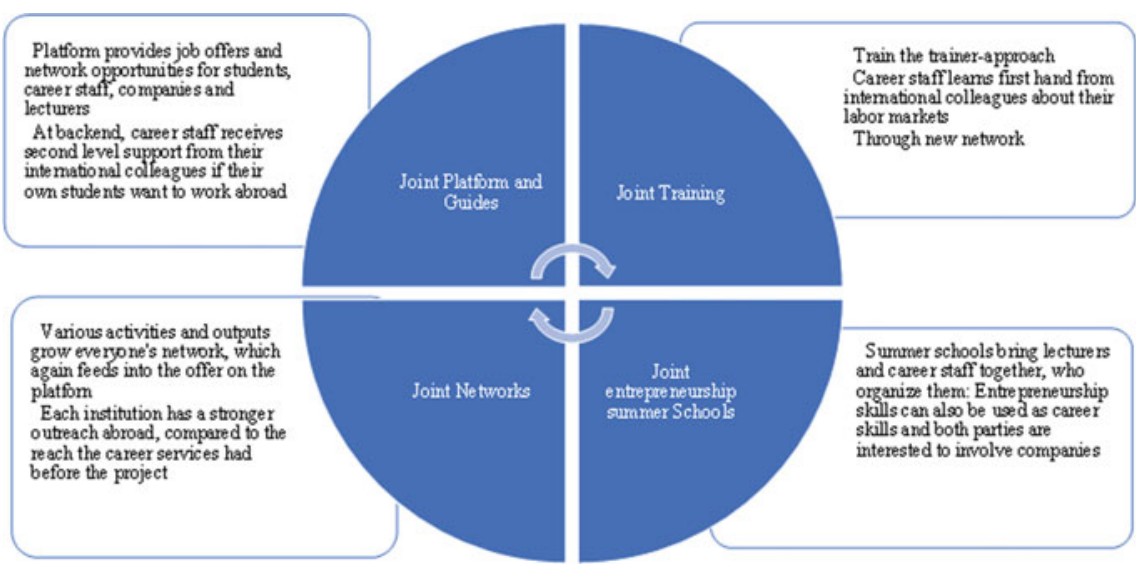

Fig. 1 ECCE model 
Table 1 Results of the ECCE model

\begin{tabular}{l|l}
\hline Career service & $\begin{array}{l}\text { Officers who participated in the training expressed high satisfaction } \\
\text { with it, felt better prepared to advise their students and appreciated the } \\
\text { exchange with their international colleagues. They also indicated that } \\
\text { the training led to increased overall work satisfaction because they had } \\
\text { better target-specific materials at hand to advise both inbound and } \\
\text { outbound students. International job offers overall had increased, } \\
\text { although language remained a major obstacle to mobility. }\end{array}$ \\
\hline Summer Schools & $\begin{array}{l}\text { The participants in the summer schools expressed extremely high } \\
\text { satisfaction with the learning outcomes and the execution of the } \\
\text { training; appreciated the enlargement of their international networks } \\
\text { and oftentimes stayed in contact with their peers, leading to valuable } \\
\text { ongoing collaboration; several participants went on to put their } \\
\text { learning into practice by funding their own businesses, which led to } \\
\text { spin-off projects. }\end{array}$ \\
\hline Collaboration & $\begin{array}{l}\text { The collaboration between the universities led to increased } \\
\text { international academic cooperation and to a larger network of } \\
\text { entrepreneurs, academics, administrators and students supporting each } \\
\text { other with advice and contacts. From initially five project managers, } \\
\text { there are now more than 50 staff (academics and administration) } \\
\text { contributing to the success of the project from across institutions and } \\
\text { institutional levels, as well as external stakeholders. }\end{array}$ \\
\hline $\begin{array}{l}\text { Currently, each institution has nominated a liaison career officer, } \\
\text { which helped to transform the initiative from a project phase into } \\
\text { institutionalisation. Other institutions outside the network can benefit } \\
\text { from the ECCE experiences in terms of utilising several outputs which } \\
\text { have been produced by the project team, such as a European career } \\
\text { advisor curriculum, which synthesises the learnings of the staff weeks, } \\
\text { the ECCE-concept paper, which documents the project and key } \\
\text { lessons, parts of the platform to enlarge the entrepreneurship } \\
\text { community, and/or a career guide for the involved partner countries, } \\
\text { specifically written with international students in mind (ECCE 2017a). }\end{array}$ \\
\hline Institutions &
\end{tabular}

tries, and to keep this spirit alive over time and personnel turnover. The advantage of small consortia compared to larger associations is that the colleagues know each other faster and better' (ECCE 2017b).

\section{Conclusions}

From a global perspective, institutional engagement has made it possible to develop career services to afford students a better chance of insertion into the job market. Those universities that have specialised support services in that direction are more likely to attract students. In this paper, we dealt with the new challenges that European career services have to face due to internationalisation and how consortiums could support such a demanding task. Given the challenges of extremely hetero- 
genic economies and career service landscapes internationally, smooth global work mobility facilitated by HEIs will remain a long-term goal.

The power of consortia is based on the fact that they enable both large and small, private and public institutions, and like-minded people to come together to try to solve the problems facing higher education and create services that satisfy the needs of all users. The ECCE results indicate that a lot of small, actively cooperating networks could have a larger impact and offer more helpful student-centred support than large associations would be able to, though they would not necessarily need to compete, but could complement each other. Personal relations will be key if we want career officers to not only broaden their perspectives but also obtain the tools necessary to assist students on a larger scale.

These transnational models have a lot of potential to add a new dimension to already existing EU-wide university networks. The challenge going forwards is to find sustainable funding models and to scale the operations for a larger input.

At an individual level or through alliances, international collaboration should be at the core of HEIs in order to govern resources and provide the infrastructures needed to enable students to face new and future challenges Our case study highlights how networks of engaged professionals from differing institutions were able to establish a quick and transparent communication system to organise a series of actions involving academics, entrepreneurs, students and career services staff. This professional integration has generated better networking, providing students with a clearer perception of the European labour market than was previously possible. However, all those benefits need to be channelled by administrations to continue in the long run and not remain a project-funded case study.

\section{References}

Böhm, T., \& Brandl, K. (2014). Umfrage zur Internationalisierung der Career Services [PowerPoint slides] Retrieved from: https://www.hrk.de/fileadmin/migrated/content_uploads/ Umfrage_Internationalisierung_Auswertung.pdf

Cojocariu, V-M. \& Puiu, M. (2014). Career-Counselling Practices for University Students. Procedia - Social and Behavioral Sciences 149, 222-227. Retrieved from: https://www.researchgate.net/ publication/266620392_Career_-_Counselling_Practices_for_University_Students.

Council on Education. (2016). Internationalizing the co-curriculum: Internationalization and student affairs. Washington, United States: American Council on Education. Retrieved from: http:// www.acenet.edu/news-room/Pages/Internationalization-in-Action.aspx

CSND (2015). Ausgangslage der Career Services an deutschen Hochschulen. Berlin.

De Wit, H., \& Merkx, G. (2012). The history of internationalization of higher education. The SAGE handbook of international higher education, 43-57.

Do Céu Taveira M. \& De Nazaré, M. (2014). Higher Education Quality and Guidance : efficacy of a career celf-management seminar for undergraduates. Revista Electrónica Interuniversitaria de Formación del Profesorado, 17 (3), 93-104.

Ebersberger, B., Herstad, S. J., \& Altmann, A. (2012). Higher education institutions and regional development. In Universities in Change (pp. 311-321). Springer, New York, NY. American.

ECCE (2015). ECCE-Project-Proposal. EBC Hochschule. Unpublished project application for NADAAD. 
ECCE (2017a). ECCE-Interim-Report. EBC Hochschule. Unpublished project report for NADAAD.

ECCE (2017b). ECCE-Concept Paper. Retrieved from: https://www.ecce.network/files/ECCEtransfer-paper.pdf

ECGFIM (2015). Train and Retain Career Support for International Students in Canada, Germany, the Netherlands and Sweden. SVR's Research Unit: Study 2015-2. Retrieved from: https://www. svr-migration.de/wp-content/uploads/2015/08/Study_Train-and-Retain_SVR-research-unit_ WEB.pdf

Eimer, A. (2014). Erreichen Career Services ihre langfristigen Ziele? Versuch einer indirekten Wirkungsanalyse. career service papers, 12/14, 66-76. Berlin.

European Union, European Parliament. (2015).Internationalisation of higher education. Brussels.

European Commission. (2018a). Erasmus+ programme annual report 2016. Brussels. Retrieved from: https://ec.europa.eu/programmes/erasmus-plus/sites/erasmusplus2/files/annual_report_ 2016.pdf.

European Commission. (2018b). Erasmus+ programme guide. Version 2 (2018): 15/12/2017. Retrived from: https://ec.europa.eu/programmes/erasmus-plus/sites/erasmusplus2/files/ erasmus-plus-programme-guide2_en.pdf.

European Commission (2015). Erasmus + programme annual report 2014. Brussels. Retrieved from: http://ec.europa.eu/dgs/education_culture/repos-itory/education/library/statistics/erasmusplus-annual-report_en.pdf.

European Commission. (2014). The Erasmus Impact Study. Luxembourg: Publications Office of the European Union, 2014. doi: https://doi.org/10.2766/75468

Hudzik, J. K. (2014). Comprehensive internationalization: institutional pathways to success. Routledge.

Kelo, M., Rogers, T., \& Rumbley, L. E. (2010). International student support in European higher education: needs, solutions, and challenges. Lemmens Medien.

Kenyon, M. A., \& Rowan-Kenyon, H. T. (2014). The Globalization of Career Services. New Directions for Student Services, (148), 93-102.

Knight, P., \& Yorke, M. (2003). Assessment, learning and employability. McGraw-Hill Education (UK).

Larrance, A. J. (2002). Expanding Resources: Benefits to Colleges and Universities. New Directions for Higher Education, 120, 3-9.

Merriam, S. B. (1998). Qualitative Research and Case Study Applications in Education in SearchWorks Catalog. San Francisco: Jossey-Bass Publishers.

Mikuláš, J., \& Jitka, S. (2019). Statistical analysis of study abroad experiences of international students in five major host countries of Europe. Journal of International Students, 9(1), 1-18.

Martirosyan, N. M., Bustamantea, R. M., \& Saxon, D. P. (2019). Academic and social support services for international students: Current practices. Journal of International Students, 9(1), $172-191$.

OECD (2013). Education at a Glance 2013: OECD Indicators, OECD Publishing. http://dx.doi.org/ 10.1787/eag-2013-en

Perez-Encinas, A. (2017). International Student Exchange Experience: Formal and Informal Support Services in the Host University. Autonomous University of Madrid: Unpublished doctoral dissertation.

Qareer (2017). Quality of Career Services. Toward a European Reference Framework.Retrieved from: https://qareer.ro/images/2016/QAREER_O1_O4_Quality_of_career_services_report.pdf

Ridder, H.-G. (2016). Case study research: Approaches, methods, contribution to theory. Mering. Simons, H. (2009). Case Study Research in Practice. London: SAGE.

Stake, R E. (1995). The Art of Case Study Research. London, New Delhi: SAGE.

Sultana, R. G., ed. (2017). Career Guidance and Livelihood Planning across the Mediterranean: Challenging Transitions in South Europe and the MENA Region. Rotterdam: Sense Publisher. 
Taveira, M. Do Céu (2017). Career Education and Guidance Services in Portugal. In Career Guidance and Livelihood Planning across the Mediterranean: Challenging Transitions in South Europe and the MENA Region, edited by Ronald G. Sultana, Rotterdam: Sense Publisher, 401-18. Van Mol, C. (2017). Do employers value international study and internships? A comparative analysis of 31 countries. Geoforum, 78, 52-60.

Vinagre, M. (2016). Developing Key Competences for Life-Long Learning through Virtual Collaboration. In Handbook of Research on Foreign Language Education in the Digital Age. IGI Global, 2016. https://doi.org/10.4018/978-1-5225-0177-0.ch008.

Yin, R. K. (2009). Case Study Research: Design and Methods. SAGE.

Yin, R. K. (2018). Case study research and applications: Design and methods. SAGE.

Yorke, M. (2006). Employability in higher education: what it is-what it is not (Vol. 1). York: Higher Education Academy.

Open Access This chapter is licensed under the terms of the Creative Commons Attribution 4.0 International License (http://creativecommons.org/licenses/by/4.0/), which permits use, sharing, adaptation, distribution and reproduction in any medium or format, as long as you give appropriate credit to the original author(s) and the source, provide a link to the Creative Commons license and indicate if changes were made.

The images or other third party material in this chapter are included in the chapter's Creative Commons license, unless indicated otherwise in a credit line to the material. If material is not included in the chapter's Creative Commons license and your intended use is not permitted by statutory regulation or exceeds the permitted use, you will need to obtain permission directly from the copyright holder.

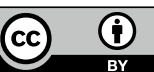

